\title{
Синтез и сорбционные свойства металл-углеродного сорбента на основе шунгита, модифицированного серебром
}

\author{
Гончарова И.С., Полунина И.А., Полунин К.Е., Буряк А.К. \\ ФГБУН Институт физической химии и электрохимии им. А.Н. Фрумкина РАН, Москва
}

Поступила в редакцию 3.07.2018 г.

DOI: https://doi.org/10.17308/sorpchrom.2018.18/592

Синтезированы металл-углеродные сорбенты на основе высокодисперсного пористого шунгита, модифицированного серебром. Методами энергодисперсионного рентгеновского микроанализа, дисперсионного анализа и поверхностно-активированной масс-спектрометрии с лазерной десорбцией / ионизацией исследованы физико-химические свойства металл-углеродных материалов и их сорбционные свойства по отношению к фенолу. Установлено, что серебро прочно удерживается на поверхности шунгита и его ионизация затруднена. Поверхностных кластеров, содержащих молекулы фенола и серебра, на поверхности металл-углеродного сорбента, модифицированного фенолом, не обнаружено. Модифицирование шунгита серебром способствует увеличению дисперсности его водных суспензий в результате усиления гидрофильных свойств шунгита.

Ключевые слова: шунгит, серебро, наночастицы, модифицирование, металл-углеродный сорбент, фенол.

\section{Synthesis and sorption properties of the metal-carbon sorbent on the base of shungite modified with silver}

\author{
Goncharova I.S., Polunina I.A., Polunin K.E., Buryak A.K. \\ A.N. Frumkin Institute of Physical Chemistry and Electrochemistry, Russian Academy of Sciences, Moscow
}

The metal-carbon sorbents based on ultradispersed porous shungite modified with nanoparticles of silver in the reverse-micellar solutions were synthesized. Physical-chemical properties of the metal-organic materials were investigated by energy-dispersive X-ray analysis (EDX) and surface-assisted massspectrometry with laser desorption / ionization method (SALDI-MS). It was observed that nanoparticles of silver are distributed on the shungite surface uniformly and retain strongly at the sorbent with $75 \%$ shungite carbon. The process of silver ionization on the shungite surface is hampered. Low desorption of silver from the modified surface of ultradispersed porous shungite, as well as the thermal stability of shungite near $500^{\circ} \mathrm{C}$ makes it possible the avoidance of the metal loss during filtration and regeneration. The adsorption of phenol on the shungite modified with nanoparticles of silver was studied by SALDI-MS. No clusters containing molecules of phenol and silver were found on the metal-carbon sorbent after adsorption of phenol. There is no interaction of phenol and silver nanoparticles on the shungite surface. The dispersity and hydrophilicity of the shungite powder in water were increased due to the modification of its surface with silver nanoparticles. It was proposed that silver modified shungite can be stable and effective sorbent for purifying of water and it is resistant to the regeneration processes. Thus metal-carbon sorbent based on ultradispersed porous shungite modified with silver can serve as a basis for producing of the new class of hybrid organic-inorganic materials for nanotechnology. A complex of hydrophilic, hydrophobic, acidic, basic, and bactericidal properties, appearing in the composition of shungite modified with silver nanoparticles, makes possible its application as sorbent, filler, catalyst and component of composite materials for medical application.

Keywords: shungite, silver, nanoparticles, modification, metal-carbon sorbents, phenol 


\section{Введение}

Модифицирование поверхности разнообразных материалов широко используется для решения актуальных задач современной науки, техники и технологии. В результате механохимического модифицирования минерального шунгита-III нами был получен высокодисперсный пористый шунгитовый материал $[1,2]$, который мог бы стать основой для создания нового класса гибридных органо-неорганических сорбентов. Шунгитовые породы Карелии содержат до 90\% углерода, оксиды и соли металлов, проявляет донорные, акцепторные, кислотные и основные свойства [3]. Углеродные материалы с развитой поверхностью часто используются в качестве инертных носителей каталитически активных соединений [4]. В отличие от угля шунгит не является инертным носителем катализаторов. Он обладает собственными каталитическими свойствами, которые могут быть значительно усилены путем иммобилизации на его поверхности переходных металлов и их соединений [3]. Серебро в сочетании с углеродными материалами широко используется для катализа, его содержание в классических катализаторах может достигать $10 \%$ [5]. К тому же установлено, что многие материалы, модифицированные серебром, обнаруживают сильные бактерицидные свойства и способны сдерживать рост и размножение бактерий $[6,7]$. В виду востребованности серебряных композитов и дороговизны их производства представляет интерес разработка новых гибридных композиционных материалов с меньшим содержанием металла, но при этом не уступающих в каталитической и бактерицидной активности традиционным материалам. Это может быть достигнуто путем нанесения наночастиц серебра на ультрадисперсные пористые сорбенты. Значительное внимание при решении таких многоплановых задач уделяется разработке активных и дешевых каталитических систем при максимальном использовании существующих природных ресурсов. Шунгит обладает высокой механической прочностью, истираемостью, термостабильностью, он полностью удовлетворяет требованиям дешевизны, доступности и экологической безопасности.

Цель работы - синтез и исследование физико-химических свойств металлуглеродных сорбентов на основе высокодисперсного пористого шунгита, модифицированного нанодисперсным серебром. Для синтеза наночастиц серебра в данной работе использован метод радиационно-химического восстановления в обратномицеллярных растворах, предложенный в [8-11].

\section{Эксперимент}

В работе использовались химически чистые реактивы фирмы Merck (фенол, изооктан, натриевая соль бис-(2-этилгексил)сульфосукцината, нитрат серебра). В качестве сорбента использовали порошок минерального шунгита-III из месторождения «Зажогино» (Карелия, Россия), который был подвергнут механохимической и ультразвуковой дезинтеграции [1]. Удельная поверхность исходного и модифицированного сорбентов, определенная по низкотемпературной адсорбции азота, составляла 2 и $71 \mathrm{~m}^{2} / \Gamma$, соответственно. В результате модифицирования суммарный объем пор шунгита увеличился с 0.046 до $0.336 \mathrm{~cm}^{3} / \Gamma$, а количество углерода в обогащенном шунгитовом материале выросло с 39 до 75\% [1]. Дисперсность порошков шунгита определялась на приборе Zetasizer Nano S (Malvern Instrument Ltd., Великобритания).

Металл-углеродные сорбенты были получены путем иммобилизации наночастиц серебра при $25^{\circ} \mathrm{C}$ на шунгите. Для этого к обратно-мицеллярному раствору наночастиц серебра добавляли измельченный шунгит, суспензию перемешивали, выдерживали в течение 1 ч, после чего осадок отфильтровывали, высушивали на воздухе и исполь- 
зовали в экспериментах. За ходом адсорбции наблюдали по изменению интенсивности характерного пика оптического поглощения серебра в обратных мицеллах при 400-420 нм [8].

Обратно-мицеллярный раствор наночастиц серебра был синтезирован в ООО «Лаборатория нанокомпозитных материалов» (Москва, РФ) по методике, разработанной в [9-11], путем радиационно-химического восстановления металла ( $\gamma$-излучение ${ }^{60} \mathrm{Co}, 15$ кГр) в $0.15 \mathrm{M}$ растворе АОТ (натриевая соль бис-(2-этилгексил) сульфосукцината) в изооктане после добавления 0.3 М водного раствора $\mathrm{AgNO}_{3}$.

Детектирование процессов образования и адсорбции наночастиц серебра на шунгите осуществлялось методом спектрофотомерии на воздухе с помощью двулучевого сканирующего спектрофотометра Shimadzu UV-2450 (Япония) с кварцевыми кюветами и длиной оптического пути 1 и 10 мм. Измерения проводились относительно раствора сравнения - 0.15 М раствора АОТ в изооктане. Микрофотографии образцов исходного и модифицированного серебром шунгита были получены на микроскопе Motic BA210 с фотокамерой Moticam 1000 (Motic, Испания). Элементный анализ поверхности сорбентов проводили методом энергодисперсионного рентгеновского микроанализа (EDX) с помощью растрового электронного микроскопа Oxford Instruments с детектором INCA X-act (Oxford Instruments, Великобритания).

Шунгит, молифицированный серебром, до и после адсорбции фенола из водных растворов (250 мкмоль/дм $\left.{ }^{3}\right)$ изучали методом поверхностно-активированной масс-спектрометрии с лазерной десорбцией/ионизацией (ПАЛДИ-МС) на времяпролетном масс-спектрометре Bruker Daltonics Ultraflex II (Bruker, Германия), оснащенном азотным лазером (длина волны 337 нм, максимальная энергия 110 мкДж, частота импульсов - 20 и 50 Гц, количество импульсов 25-50; время между импульсами 1 мкс) в диапазоне $\mathrm{m} / \mathrm{z}, 20-2000$. Использовали режим работы прибора для регистрации положительных ионов [12].

\section{Обсуждение результатов}

Использованный в данной работе метод радиационно-химического восстановления подразумевает, что наночастицы серебра образуются при восстановлении их ионов гидратированными электронами или другими продуктами радиолиза воды в деаэрированных водно-органических обратно-мицеллярных растворах $\mathrm{Ag}^{+} / \mathrm{H}_{2} \mathrm{O} / \mathrm{AOT/изооктан.} \mathrm{В} \mathrm{дальнейшем} \mathrm{происходит} \mathrm{агрегация} \mathrm{первоначальных} \mathrm{нано-}$ частиц и формирование стабильных наноразмерных агрегатов $\mathrm{Ag}_{\mathrm{n}}{ }^{\mathrm{m}+}$ (где $\mathrm{n}>\mathrm{m}$ ). Ocновным фактором, определяющим размер и форму обращенных мицелл, в которых формируются наночастицы серебра в данной системе, является степень гидратации, или коэффициент солюбилизации, обращенных мицелл $\omega=\left(\mathrm{H}_{2} \mathrm{O} / \mathrm{AOT}\right)=8$.

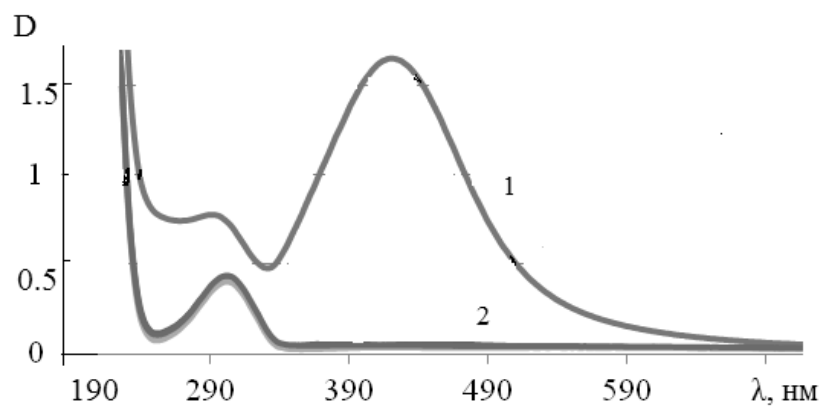

Рис. 1. Спектр оптического поглощения наночастиц серебра в обратно-мицеллярном растворе до и после внесения шунгита в суспензию (кривые 1 и 2 , соответственно). 
Как видно на рис. 1, в обратно-мицеллярном растворе спектры оптического поглощения серебра имеют мало интенсивную полосу поглощения в области 270320 нм и интенсивную полосу поглощения в области 390-450 нм (рис. 1, крив. 1). По данным [13], мицеллярный раствор наночастиц серебра представляет собой суперпозицию его наночастиц разного размера, формы и заряда. Полоса поглощения в области 270-320 нм соответствует сферическим наночастицам $\mathrm{Ag}_{2}{ }^{+}$размером $12 \mathrm{Hм}$, а полоса поглощения в области 390-450 нм - эллипсоидным кластерам $\mathrm{Ag}_{4}{ }^{2+}$ размером $27 \mathrm{Hм}$ [13]. Исследование эволюции спектров оптического поглощения обратномицеллярной системы $(\omega=8)$ при формировании композитов шунгит - наночастицы серебра позволяет отметить, что уже через несколько минут после введения шунгита в обратно-мицеллярный раствор наночастиц серебра происходит уменьшение интенсивности полосы поглощения крупных агрегатов наночастиц $\mathrm{Ag}\left(\lambda_{\text {макс }} \approx 421\right.$ нм$)$, т.е. идет их адсорбция на шунгите. По данным $[13,14]$, на угле также первыми адсорбируются крупные наночастицы $(\lambda=540$ нм), а на силикагеле, напротив, - первыми адсорбируются мелкиенаночастицы $(\lambda=260$ нм).

Методом EDX в основном элементном составе поверхности модифицированного серебром шунгита (рис. 2) было обнаружено $1.33 \%$ серебра (масс.). Кроме основных химических элементов в его составе были идентифицированы микропримеси $\mathrm{P}, \mathrm{Mn}$ и W (0.01-0.06 \% масс.); Li, Cr, Ni, Sr, Ba (0.002-0.005 \%); V, Co, Ga, Y, Zr, Nb, Mo, $\mathrm{Hg}(0,0001-0,0007 \%)[1,2]$.

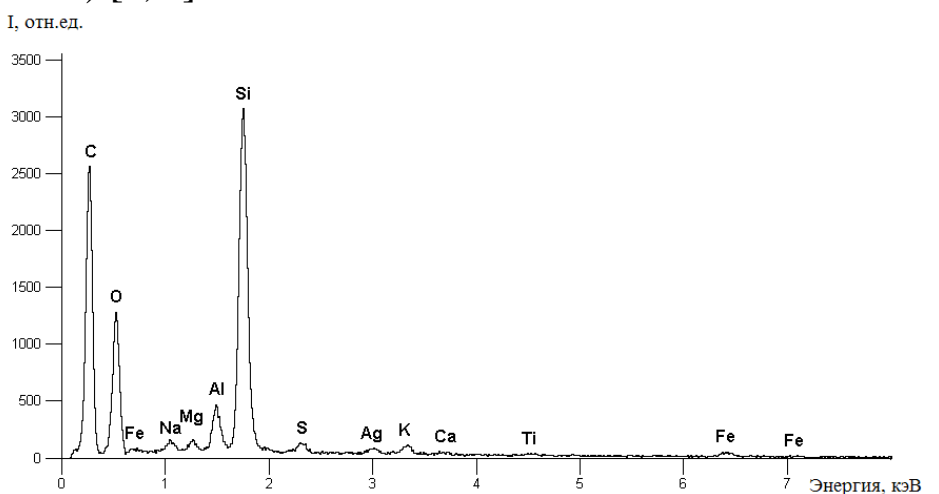

Рис. 2. Спектр EDX микроанализа поверхности шунгита после его модифицирования наночастицами серебра.

Соединения серебра легко ионизируются и образуют кластерные ионы [12]. Это облегчает их исследование методами масс-спектрометрии с лазерной десорбцией/ионизацией. На рис. 3 приведен масс-спектр ПАЛДИ образца высокодисперсного шунгита, содержащего наночастицы серебра. Облучение модифицированного шунгита лазерными лучами приводит к активации его поверхностного слоя и десорбции протонированных молекул $\left(\mathrm{M} \cdot \mathrm{H}^{+}\right)$исследуемых соединений с поверхности [15]. Обнаружено, что ионизация серебра на поверхности шунгита затруднена. Пики в спектре на рис. 3 мало интенсивные с несколько искаженной формой, что свидетельствует об аккумуляции энергии лазера шунгитом, а также о малой десорбции серебра с его поверхности. В диапазоне масс 100-400 Да основной молекулярный состав образующихся соединений соответствует брутто-формулам $\left[\mathrm{KCl} \cdot \mathrm{C}_{\mathrm{x}}\right] \cdot \mathrm{H}^{+}$и $\left[\mathrm{KCl} \cdot \mathrm{C}_{\mathrm{x}}\right] \cdot \mathrm{K}^{+}$. Кроме того, в диапазоне масс 700-800 Да и 900-1000 Да наблюдаются сложные кластеры, имеющие в своём составе серебро $\left[\mathrm{Ag}_{\mathrm{x}} \mathrm{C}_{\mathrm{y}} \mathrm{KCl}\right] \cdot \mathrm{K}^{+}$и $\left[\mathrm{Ag}_{\mathrm{x}} \mathrm{C}_{\mathrm{y}} \mathrm{KCl}\right] \cdot \mathrm{Ag}^{+}$. Малая десорбции серебра с поверхности высокодисперсного пористого шунгита, а также термостойкость шунгита вплоть до $500^{\circ} \mathrm{C}$ [1] позволит избежать потерь металла во время эксплуатации очистительных фильтров на его основе и проводить термическую регенерацию сорбента. 


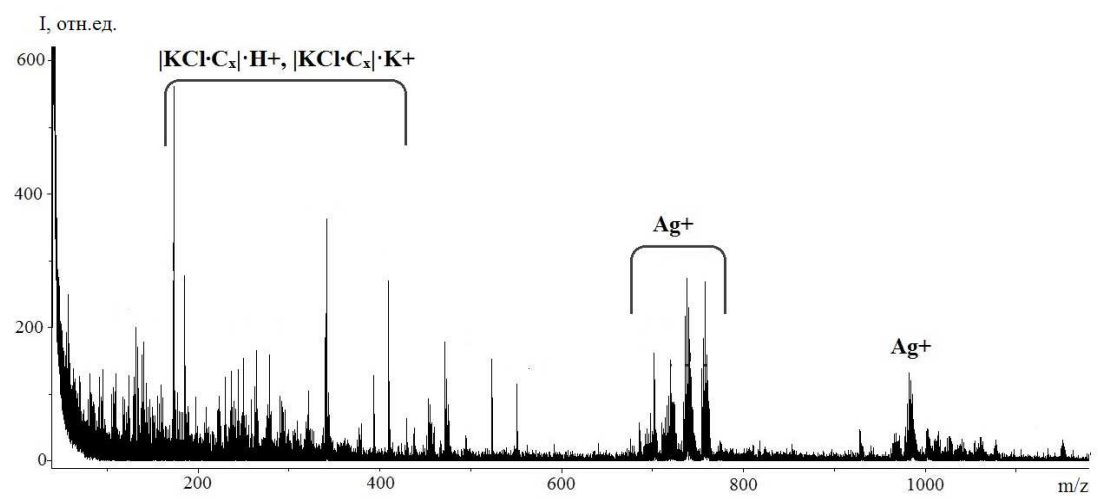

Рис. 3. Спектр ПАЛДИ, полученный в режиме регистрации положительных ионов с поверхности шунгита, выдержанного в растворе соли серебра. Символом « $\mathrm{Ag}^{+} »$ обозначены кластеры, имеющие в своём составе катионы серебра.

Вода сорбируется на шунгите, главным образом, за счет специфических водородных связей и является идеальным тестом на гидрофильность поверхности. В отличие от сажи и графита, вода хорошо смачивает шунгит, т.к. в его составе имеются гидрофильные минералы. Однако модифицирование шунгита наночастицами серебра и его агломератами $\mathrm{Ag}_{\mathrm{n}}{ }^{\mathrm{m}+}$ может привести к замене протонов поверхностных $\mathrm{OH}$ групп на катионы серебра и осаждению мицеллообразующих ПАВ на поверхностных адсорбционных центрах.

На рис. 4 приведены результаты дисперсионного анализа водных суспензий шунгита до и после его модифицирования наночастицами серебра. Там же приведены микрофотографии этих суспензий. Как видно, модифицирование шунгита серебром способствует увеличению дисперсности его водных суспензий. Это является результатом повышения гидрофильности твердой фазы в результате поляризации структурной и сорбированной воды ионами и наночастицами металла. Аналогичные результаты были получены нами для минерального шунгита-III, модифицированного серебром, а также в работах $[7,14]$ для модифицированных серебром оксидов кремния, алюминия и алюмосиликатов.

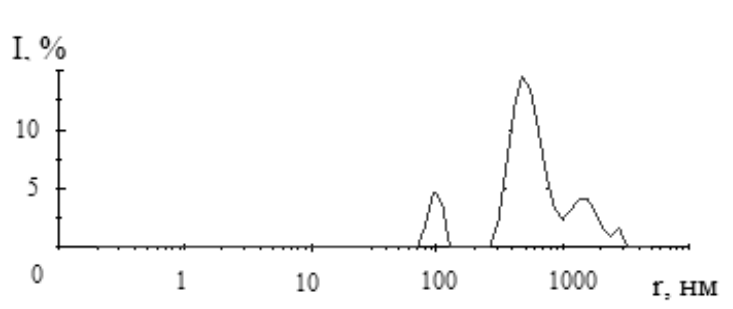

a

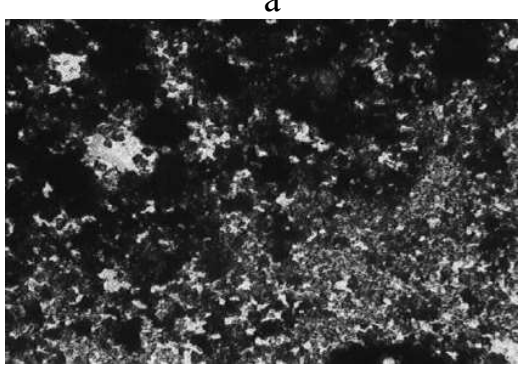

B

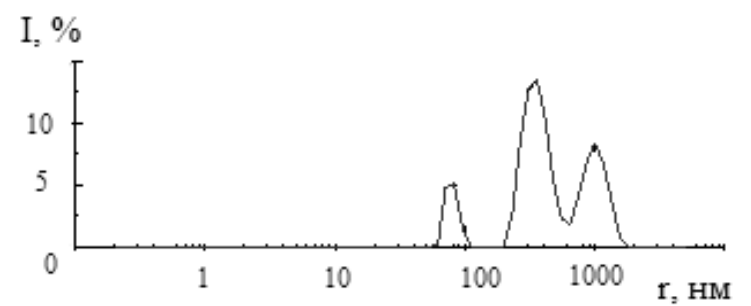

6

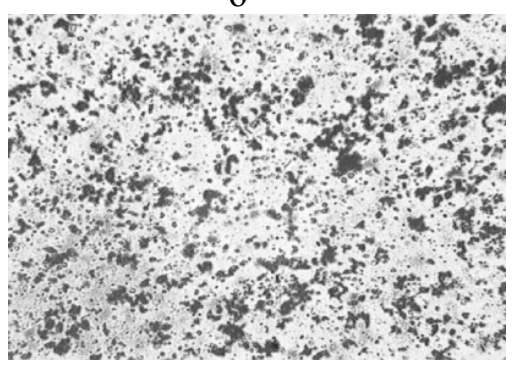

$\Gamma$

Рис. 4. Распределение по размерам частиц шунгита до и после их модифицирования серебром в водных суспензиях (а и б; соответственно); микрофотографии водных суспензий шунгита до и после модифицирования шунгита серебром

(в и г; соответственно). 
Известно, что 99\% объема пор минерального шунгита-III приходится на макропоры размером 200 нм и более [3]. Структура пор высокодисперсного шунгита, по нашим данным [2], несколько иная (большинство пор имеет размеры 10-100 нм), а его суммарная пористость в 10 раз больше, чем у минерального шунгита-III. Синтезированные нанокластеры серебра преимущественно имеют размеры 12-30 нм, что создает возможность их проникновения в макро- и мезопоры шунгита, а также между ламелями, т.е. пачками из конденсированных слоев шунгитового текстурированного углерода в силикатной матрице [3]. Это увеличивает размер каталитически активной поверхности гибридного сорбента, а также стабилизирует наночастицы серебра в материале благодаря дисперсионным взаимодействиям [4]. Возможность дополнительного удерживания серебра в межслоевом пространстве шунгитового углерода выгодно отличает шунгит от керамических и угольных сорбентов и имеет практическое значение.

В $[13,14]$ показано, что появление на поверхности оксидов кремния и алюминия серебра, как в форме наночастиц, так и в ионной форме, увеличивает адсорбцию спиртов, ароматических и кислородсодержащих углеводородов за счет специфической составляющей. Одновременно модифицирование этих гидрофильных сорбентов снижает сорбцию неполярных веществ. Шунгит - гибридный органонеорганический сорбент, поэтому одинаково хорошо сорбирует как полярные, так и неполярные соединения, что делает его ценным сорбентом для использования в различных фильтрах [4, 7]. Практический интерес представляло исследование взаимодействия фенола с поверхностью шунгита до и после его модифицирования серебром, т.к. обработка серебром - традиционный способ придания сорбентам бактерицидных свойств. На рис. 5 приведены спектры ПАЛДИ десорбированного фенола с поверхности шунгита до и после его модифицирования наночастицами серебра в $0.001 \mathrm{M}$ растворе $\mathrm{AgNO}_{3}$ в присутствии формальдегида в качестве восстановителя. Результаты эксперимента показали, что основными продуктами ионизации фенола на поверхности исходного шунгита и шунгита, модифицированного серебром, являются молекулярный ион фенола, заряженные аддукты фенола с натрием и калием и протонированная молекула димера фенола. Выявлено образование фенолятов в протонированной форме. Кластеров состава $\left(\mathrm{nM} \cdot \mathrm{Ag}^{+}\right)$, содержащих молекулы фенола и серебра, обнаружено не было. Тенденции образования аддуктов с щелочными металлами у димера фенола не наблюдалось. Таким образом, нанесение серебра на шунгит практически не влияет на ионизацию фенола, т.е. фенол не взаимодействует с ионами и наночастицами серебра. С другой стороны, ранее в [15] было обнаружено, что масс-спектры ПАЛДИ фенола, десорбированного с поверхности образцов шунгита, содержащих 76 и 0\% углерода, практически одинаковы, т.е. фенол преимущественно сорбируется на неорганических компонентах шунгита, образуя с ними достаточно прочные связи. В [16] был установлен химический характер взаимодействия фенола с шунгитом, приводящий к каталитическому окислению сорбированного фенола на воздухе до нетоксичных простых соединений. Поскольку лишь небольшая часть поверхности шунгита покрыта серебром (1.3\% масс.), то центры специфической адсорбции фенола остаются свободными. Эти донорно-акцепторные поверхностные центры шунгита (ионы переходных металлов) катализируют окисление и деструкцию молекул фенола. Присутствие ионов и наночастиц серебра лишь увеличивает их кислотность [7, 14]. Таким образом, шунгит, модифицированный серебром, сможет проявлять как бактерицидные, так и каталитические свойства. Затрудненная десорбция серебра с поверхности шунгита позволит избежать потерь металла во время его эксплуатации и регенерации. Это особенно важно для стабильной работы очистительных фильтров, т.к. серебро с поверхности керамики, угля и силикаге- 
ля постепенно вымывается водой и вытесняется катионами жесткости. В результате поверхность таких сорбентов теряет свои бактерицидные свойства, а концентрация серебра в очищаемой воде многократно превышает ПДК (50 мкг/дм $\left.{ }^{3}\right)$ [7].

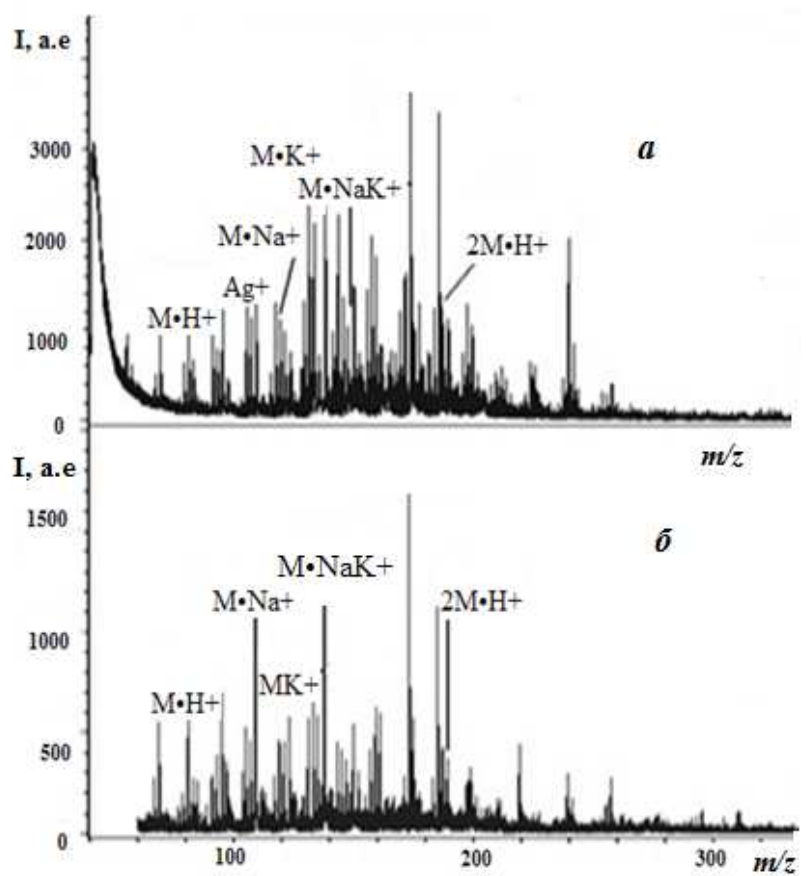

Рис. 5. Масс-спектры ПАЛДИ модифицированных фенолом образцов шунгита с наночастицами серебра (а) и исходного шунгита (б). Буквой М обозначена ионизированная молекула фенола.

Проведенные исследования свидетельствуют о том, что шунгит, являясь дешевым многотоннажным, экологичным сорбентом, имеет потенциал для создания новых технологичных материалов на его основе - гибридных органонеорганических композитов, поры которых в углеродной или керамической матрице заполнены металлами или сторонними материалами различной природы. Знакопеременная поверхность металл-углеродных сорбентов на основе шунгита несет широкий спектр сорбционных центров разной природы и силы, проявляя способность к сорбции, катализу и деструкции сорбированных веществ. Доказательство тому - обнаруженная трансформация различных органических соединений в поверхностном слое шунгита $[3,15,17]$. Все это открывает возможность синтеза новых гибридных органо-неорганических материалов как широкого спектра действия, так и узкоцелевого назначения.

\section{Заключение}

Синтезированы металл-углеродные сорбенты на основе высокодисперсного пористого шунгита (содержащего 75\% углерода), и наночастиц серебра. Шунгит модифицировали серебром в обратно-мицеллярных растворах. Методами EDX и ПАЛДИМС установлено присутствие серебра на поверхности модифицированного шунгита в виде кластеров $\left[\mathrm{Ag}_{\mathrm{x}} \mathrm{C}_{\mathrm{y}} \mathrm{KCl}\right] \cdot \mathrm{Ag}^{+}$и $\left[\mathrm{Ag}_{\mathrm{x}} \mathrm{C}_{\mathrm{y}} \mathrm{KCl}\right] \cdot \mathrm{K}^{+}$. Обнаружено, что ионизация серебра на поверхности шунгита затруднена. Наноразмерное серебро прочно удерживается на поверхности и в порах сорбента, содержащего $76 \%$ углерода. Это позволит избежать потерь металла во время эксплуатации очистительных фильтров для воды и их последующей регенерации. Исследованы физико-химические свойства металлуглеродных материалов и их сорбционные свойства по отношению к фенолу. Кла- 
стеров состава (nM· $\left.\mathrm{Ag}^{+}\right)$, содержащих молекулы фенола и серебра, на поверхности шунгита не обнаружено, т.е.фенол не взаимодействует с ионами и наночастицами серебра, а адсорбируется на кислотно-основных поверхностных центрах шунгита. Это позволяет шунгиту приобретать бактерицидные свойства, одновременно сохраняя свои каталитические свойства. Модифицирование шунгита серебром способствует увеличению дисперсности его водных суспензий в результате усиления гидрофильных свойств поверхности.

\section{Авторы благодарят РФФИ за финансовую поддержку работы}

(проекты № 18-08-01224 и 17-08-00315), а также ООО «Лаборатория нанокомпозитных материалов» (Москва) за предоставление наноразмерных частии серебра и Центр коллективного пользования ИФХЭ РАН за помощь в исследовании металлуглеродных сорбентов.

\section{Список литературы}

1. Полунина И.А., Гончарова И.С., Высоцкий В.В., Полунин К.Е. и др. // Сорбиионные и хроматографические прочессы. 2016. Т.16. № 2. C. 234-240.

2. Polunina I.A., Goncharova I.S., Visotskii V.V., Polunin K. E. et al. // Inorganic Materials: Applied Research. 2017. Vol. 8. No 1. pp. 181-185. DOI: $10.1134 / \mathrm{S} 2075113317010282$

3. Шунгиты - новое углеродистое сырье. Под ред. В.А. Соколова, Ю.К. Калинина, Е.Ф. Дюккиева. Петрозаводск. Карелия. 1984. $182 \mathrm{c}$.

4. Елисеев А.А., Лукашин А.В. Функциональные наноматериалы. под ред. Ю.Д. Третьякова. М. Физматлит. 2010. 456 с.

5. Крутяков Ю.А., Кудринский А.А., Оленин А.Ю., Лисичкин Г.В. // Успехи химии. 2008. T. 77. № 3. C. 242-269.

6. Егорова Е.М., Ревина А.А., Ростовщикова Т.Н., Киселева О.И. // Вестник Моск. Ун-та. Сер. 2. Химия. 2001. Т. 42. № 5. С. 332-338.

7. Котельникова Т.А. // Сорбционные $и$ хроматографические проиессы. 2017. Т. 17. № 5. C. 706-715.

8. Ревина А.А. // Физикохимия поверхности и защита материалов. 2009. Т. 45. №. 1. C. 58-63.

\section{References}

1. Polunina I.A., Goncharova I.S., Vysockij V.V., Polunin K.E. et al., Sorbtsionnye i khromatograficheskie protsessy, 2016, Vol. 16, No 2, pp. 234-240.

2. Polunina I.A., Goncharova I.S., Visotskii V.V., Polunin K.E. et al., Inorganic Materials:
9. Ревина А.А., Кезиков А.Н., Алексеев А.В., Хайлова Е.Б. и др. // Нанотехника. 2005. № 4. C. 105-111.

10.Ревина А.А., Баранова Е.К. // Физикохимия поверхности и защита материалов. 2010. T. 46. № 4. C. 376-379.

11.Ревина А.А. Патент РФ № 2212268. 2003.

12.Polunin K. E, Goncharova I.S., Ulyanov A.V., Polunina I.A. et al. // Colloid J. 2017. Vol.79. No 2. pp. 250-257. DOI: 10.1134/S1061933X17020090

13.Кезиков А.Н., Баранова Е.К., Хайлова Е.Б., Ревина А.А. // Сорбиионные и хроматографические прочессы. 2017. Т. 17. № 2. С. 916-923.

14.Белякова Л.Д., Коломиец Л.Н., Ларионов О.Г., Буланова А.В. и др. // Сорбиионные и хроматографические прочессы. 2007. Т. 7. №. 1. C. 98-105.

15.Polunina I.A., Goncharova I.S., Polunin K.E, Buryak A.K. // Inorganic Materials: Applied Research. 2018. Vol. 9. No 4. pp. 772776. DOI: $10.1134 /$ S2075113318040305.

16.Акимбаева А.М. // Нефтехимия. 2007. T. 47. C. 225-235.

17.Ulyanov A.V., Polunina I.A., Polunin K. E, Buryak A.K. // Colloid J. 2018. Vol. 80. No 1. pp.96-106. DOI: 10.1134/S1061933X18010131.

Applied Research, 2017, Vol. 8, No 1, pp. 181185. DOI: $10.1134 /$ S2075113317010282.

3. Shungity - novoe uglerodistoe syr'e. Pod red. V.A. Sokolova, Ju.K. Kalinina, E.F. Djukkieva. Petrozavodsk, Karelija, 1984, 182 p. 
4. Eliseev A.A., Lukashin A.V. Funkcional'nye nanomaterialy. pod red. Ju.D. Tret'jakova. Moskva, Fizmatlit, 2010, 456 p.

5. Krutjakov Ju.A., Kudrinskij A.A., Olenin A.Ju., Lisichkin G.V., Uspehi himii, 2008, Vol. 77, No 3, pp. 242-269.

6. Egorova E.M., Revina A.A., Rostovshhikova T.N., Kiseleva O.I., Vestnik Mosk. Un-ta. Ser. 2. Himija, 2001, Vol. 42, No 5, pp. 332338.

7. Kotel'nikova T.A., Sorbtsionnye i khromatograficheskie protsessy, 2017, Vol. 17, No 5, pp. 706-715.

8. Revina A.A., Fizikohimija poverhnosti $i$ zashhita materialov, 2009, Vol. 45, No. 1, pp. 58-63.

9. Revina A.A., Kezikov A.N., Alekseev A.V., Hajlova E.B. et al., Nanotehnika, 2005, No 4, pp. 105-111.

10.Revina A.A., Baranova E.K., Fizikohimija poverhnosti $i$ zashhita materialov, 2010, Vol. 46, No 4, pp. 376-379.

11.Revina A.A. Patent RF 2212268. 2003

Гончарова Ирина Сергеевна - кандидат химических наук, ИФХЭ РАН, Москва, (495) 955-44-57

Полунина Ирина Александровна - кандидат химических наук, доцент, ИФХЭ РАН, Москва, (495) 955-46-90

Полунин Константин Евгеньевич - кандидат химических наук, доцент, ИФХЭ РАН, Москва, (495) 955-46-90

Буряк Алексей Константинович - доктор химических наук, профессор, ИФХЭ РАН, Москва, (495) 955-46-85
12.Polunin K. E, Goncharova I.S., Ulyanov A.V., Polunina I.A. et al., Colloid J., 2017, Vol. 79, No 2, pp. 250-257. DOI: 10.1134/S1061933X17020090.

13.Kezikov A.N., Baranova E.K., Hajlova E.B., Revina A.A., Sorbtsionnye i khromatograficheskie protsessy, 2017, Vol. 17, No 2, pp. 916-923.

14.Beljakova L.D., Kolomiec L.N., Larionov O.G., Bulanova A.V. et al., Sorbtsionnye $i$ khromatograficheskie protsessy, 2007, Vol. 7, No 1, pp. 98-105.

15.Akimbaeva A.M., Neftehimija, 2007, Vol. 47, pp. 225-235.

16.Polunina I.A., Goncharova I.S., Polunin K.E, Buryak A.K., Inorganic Materials: Applied Research, 2018, Vol. 9, No 4, pp. 772776. DOI: $10.1134 /$ S2075113318040305.

17.Ulyanov A.V., Polunina I.A., Polunin K. E, Buryak A.K., Colloid J., 2018, Vol. 80, No 1, pp. 96-106. DOI: 10.1134/S1061933X18010131.

Goncharova Irina S. Ph.D. (chemistry) IPCE RAS, Moscow, akburyak@mail.ru

Polunina Irina A. Ph.D. (chemistry), associate prof., IPCE RAS, Moscow, polunina@phyche.ac.ru

Polunin Konstantin E Ph.D. (chemistry) associate prof. IPCE RAS, Moscow, polunin@mail.ru

Buryak Alexei K. prof., Dr.Sci. (chemistry) IPCE RAS, Moscow, akburyak@mail.ru 